\title{
Giriftzen Asım Bey'e ait Hicaz ve Ethem Bey'e ait Ușşak eserlerin, Callisto Guatelli tarafından yapılan armonizasyonlarının analizi; müzik tarihi ve müzik teorisi kapsamında değerlendirilmesi
}

\section{Doç. Sadık Uğraș Durmuș *}

İstanbul Üniversitesi, Devlet Konservatuvarı, Müzikoloji Bölümü, Türkiye, İstanbul.

Adres: Reșitpașa Mah. Emirgan Sok. No: 6/3 Sanyer/İstanbul, Türkiye.

e-Mail:sadikugrasdurmus@istanbul.edu.tr, https://orcid.org/0000-0001-7122-7390

DOI 10.12975/rastmd.20219110 Submitted June 16, 2021 Accepted August 14, 2021

\begin{abstract}
Özet
Musika-i Hümâyûn'un kurulmasıyla 19. yüzyılın ikinci çeyreğinden itibaren Batı müziğinin Osmanlı kültüründe etkinliği artmaya bașlamıș ve daha geniș kesimlerce kabul görmüștür. Giuseppe Donizetti'nin vefatının ardından bu kurumda çalıșmaya bașlayan Callisto Guatelli, devletin farklı katmanlarında șeflik, eğitmenlik ve müzisyenlik alanlarında katkı sağlamıș ve bu süreçte Batı müziği ve Türk müziği kültüründen izler tașıyan eserler bestelemiștir. Türk müziği literatüründen seçmiş olduğu bazı makamsal eserleri armonize ederek, literatüre kazandırmıștır. Batı müziği ve Türk müziği elementlerinin bir araya getirilmesi ile inșa edilen ve melez bir karakter ile örülü olan bu yapitlar, tarih, müzik estetiği ve müzik teorisi ekseninde bazı soruların doğmasına da neden olmuștur. Bu çalıșmada, bestecinin armonizasyonlarından seçilen iki parçanın armonik analizinin yapılmasının yardımı ile makamsal eserleri çokseslendirme tekniğinde izlenen yöntem eleștirel bir bakıș açısıyla ele alınmıș ve makamların bu süreçte yașadıkları kimlik değișimlerinin olası neden ve sonuçlarına odaklanılmıștır.
\end{abstract}

\section{Anahtar Kelimeler}

armonizasyon, Türk müziği, makam, Osmanlı Imparatorluğu, çokseslilik

\section{Giriș}

19. yüzyılın ikinci çeyreğinden itibaren Osmanlı'nın Batılılașma politikalarında yaşanan değișimlerin iz düşümü, müzik sanatında da gözlemlenmeye bașlanmış ve bu yönde önemli adımlar atılmıștır. $\mathrm{Bu}$ yeni dünya görüşünün hayata geçirilebilmesi için devletin kurumsal yapısında yeni yapılanmalara ihtiyaç duyulmuş ve bu süreçte Avrupa'dan müzik insanları davet edilip Musika-i Hümâyûn'da görevlendirilmiştir. Böylelikle Batı müziği kültürü, hem devletin farklı katmanlarında hem de gündelik yaşamda kabul görüp yaygınlașmaya bașlamıștır. Batı müziği ve Türk müziğinin hem saray ve çevresinde hem de toplumun farklı kesimlerinde icra ediliyor olması, bu iki müzik kültürünün etkileșimine zemin hazırlamıș ve bu iki kültürlü müzik yașantısının bir sonucu olarak, BatıDoğu kültürlerinin izlerini tașıyan pek çok müzik yapıtı bu dönemde literatüre kazandırılmıștır. Böylesine renkli bir kültürel ortamda Callisto Guatelli de bu akımın estetik çerçevesine uygun olarak Batı-Doğu lezzetlerini bünyesinde barındiran melez yapıda eserler vermeye yönelik çalıșmalar yapmıștır. Bestecilik çalıșmalarında askerî müzik karakteri tașıyan eserlerin öne çıktığını görebildiğimiz Guatelli, bunun yanında Türk müziği literatüründen seçtiği 
makamsal eserlerin armonizasyonunu da yaparak bu alanda katkı sağlamıștır. Doğrudan makam müziği literatüründen seçilip çokseslendirilen eserler, bu süreçte makamları olușturan perdelerin piyano ile seslendirilememesi nedeniyle, geleneksel tını yelpazesinden uzaklașıp daha farklı bir müzik diline doğru evrilmiștir. Özünden uzaklașan bu makamsal yapılar edindikleri bu yeni kimlik ile tonal müzik eksenine entegre edilmeye çalıșılmıștır. Bugünün penceresinden bakıldığında, yapılan bu armonizasyonların müzik estetiği perspektifinde bazı sorunlu yanları göze çarpmaktadır. Bu çalıșmada, bestecinin makamsal eserleri çokseslendirme tekniğinde izlediği yöntem eleștirel bir bakış açısıyla ele alınmış ve makamların bu süreçte yașadıkları kimlik değișimlerinin olası neden ve sonuçlarına odaklanılmıștır. Armonize edilen bu makamsal eserlerin sadece Guatelli'nin sanatçı kișiliğini değil, aynı zamanda dönemin müzik kültürünün izdüșümlerini de yansıtması sebebiyle bu çalıșmanın müzikoloji alanının farklı noktalarına katkı sağlayabileceği düșünülmektedir.

\section{Metodoloji}

$\mathrm{Bu}$ çalıșmanın kapsamı, Callisto Guatelli'nin yapmıș olduğu armonizasyonlardan seçilen iki örnek ile sınırlandırılmıștır. 19. yüzyılın son çeyreğinde dönemin müzik literatürüne kazandırılan bu iki yapıt, Batı müziği tarihi, Batı müziği teorisi ve Türk müziği teorisi perspektifinden incelenmeye çalıșılmıștır. Ele alınan yapıtların Batı müziği teorisi çerçevesinde armonik analizi yapılmıș ve çokseslendirilen makamsal eserlerin tonal müzik eksenine entegre edilebilmesine yönelik yapılan çalıșmalarda izlenen yolun aydınlatılabilmesi hedeflenmiștir. Elde edilen veriler ıșığında, armonizasyonların dokusu, armonik dili ve üslubu, Barok, Klasik ve Romantik Dönem estetiği ve yapitları ile karşılaștırılarak, müzik sanatı ile müzik tarihindeki yeri konumlandırılmaya çalıșılmıștır. Çokseslilik örgüsü içinde yer alan makamsal kurgunun yapısı, 12 ses eșit tamperaman sistemi, geleneksel makam icra pratiği ve Türk müziği teorisi penceresinden gözlemlenmeye çalıșılmıș ve bu yöntem ile ulașilan bulgular ile makamsal müziğin çokseslendirilme serüveni içindeki rolü irdelenmiștir. Armonizasyonların tașıdığı melez karakter nedeniyle, Osmanlı Devleti'nin 19. yüzyılın ikinci çeyreğinden itibaren izlediği kültür politikalarının bir uzantısı olarak değerlendirmesi gereken ve Batı müziğinin Osmanlı kültürüne entegre olma sürecinde etkisi olan değișimlerin, bu armonizasyonlar üzerindeki olası etkileri tartıșılmıștır. Dönemin öne çıkan karakteristik müzik eğilimleri ile karșılaștırılmasının yardımı ile, ele alınan bu yapıtların çok yönlü bir șekilde değerlendirilmesi hedeflenmiștir.

$\mathrm{Bu}$ alanda yapılan literatür taraması sonucunda, 2014 yılında Yasin Hanönü tarafından yazılan ve İnönü Üniversitesinde kabul edilen "Callisto Guatelli’nin 19. Yüzyıl Klasik Türk Müziği Çokseslendirme Çalıșmalarındaki Yeri, Eserlerinin Transkripsiyon ve Analizi" isimli doktora tezi incelenmiș ve bu çalıșmaya hem genel bir çerçeve modeli hem de bir motivasyon unsuru olarak katkı sağlamıștır.

Eserlerin armonik analizinin yapılabilmesine katkı sağlayan kaynaklar: Kent Wheeler Kennan, Counterpoint; Heinrich Schenker, Counterpoint; Walter Piston, Harmony; Zarife Bakihanova, 
Armoni ve Nurhan Cangal; Armoni; eserlerin makamsal yapısının analizinin yapılabilmesine katkı sağlayan ana kaynak: İsmail Hakkı Özkan, Türk Mûsıkîsi Nazariyatı ve Usulleri Kudüm Velveleleri

\section{Yüzyıl Romantik Dönem Müziğinde Piyanonun Yeri Ve Armonizasyonların Doku} Perspektifinden Değerlendirilmesi Barok Dönem'den itibaren çalgısal müziğin popülaritesi artmıș ve besteciler konçerto, sonat gibi çeşitli müzik formlarına yoğunlașarak bu alanda çok sayıda eser vermişlerdir. Çalgı müziği literatürünün gelișmesine koșut olarak, bu alanda yazılan eserlerin yapısını olușturan icra tekniğinin de sınırları genișletilmiștir. Bu gelişmelerin bir sonucu olarak, müzisyenlerin söz konusu literatürü icra edebilmesi için daha üst bir seviyede teknik beceri ile donanması gerekmiștir. ${ }^{1}$ Bu eğilim Klasik Dönem'de de gelișimini sürdürmüș ve ardından gelen Romantizm ile büyük bir sıçrama gerçekleșmiștir. Her ne kadar örneğin Barok Dönem'de A. Vivaldi (1678-1741), bestelediği konçertolarla ya da Klasik Dönem'de L.v. Beethoven'ın (17701827) piyano sonatlarıla müzisyenlerin ulașması gereken teknik seviyeler çok yukarılara tașınmış olsa da 19. yüzyıl müziği yapıtlarındaki çalgı icra tekniği sınırlarının, besteciler tarafından önceki dönemlerde görülmemiş bir biçimde zorlandığını söylememiz yanlıs olmayacaktır. N. Paganini (17821840), F. Liszt (1811-1886), F. Chopin (1810-1849) gibi virtüöz bestecilerin çeșitli formalarda yazılmış eserlerinin genelinde bu tip bir eğilimin etkileri görülebilmektedir. ${ }^{2}$
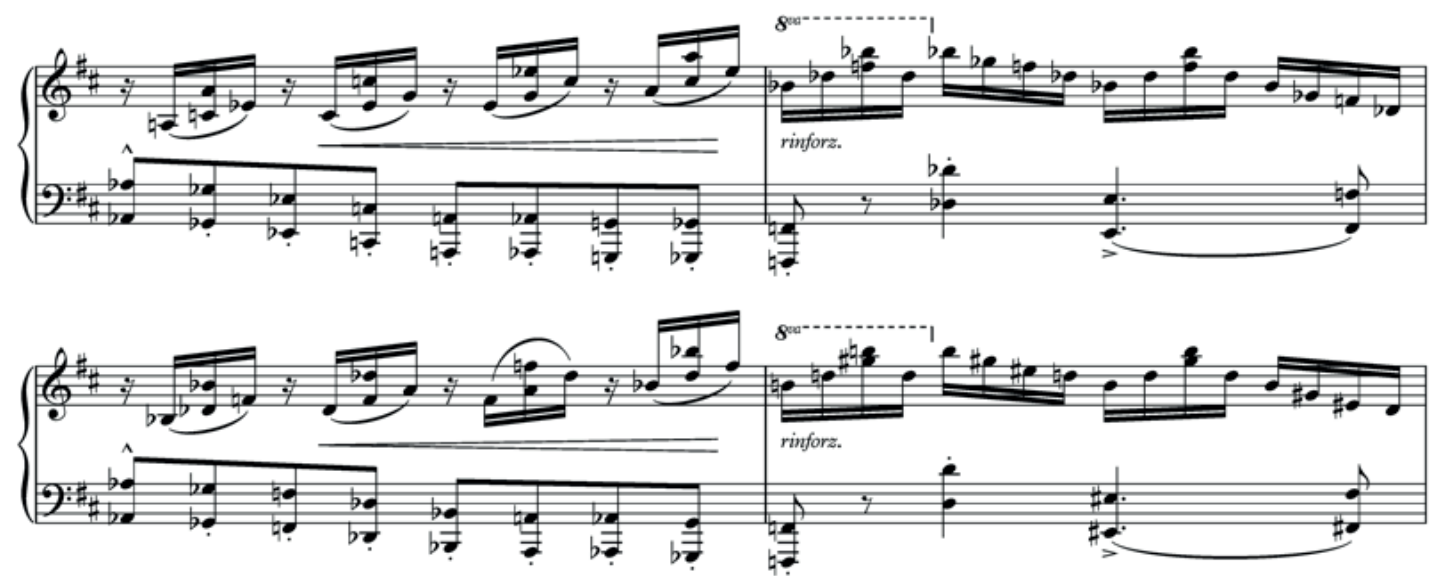

Şekil 1. F. Liszt, Si Minör Piyano Sonatı, S. 178

Romantik Dönem'de besteciler, önceki dönemlerden doku ve stil bakımından ayrıșan yeni anlatım dillerine yönelmişlerdir. Özgür ve belki dönemin ruhuna koșut olarak abartılı bir dille bezenmiș olan bu eserler literatüre kazandırılırken, bestecilerin çalgıların sunduğu teknik olanakların tümünü kullanılma eğilimi içinde olduğunu gözlemlenebilmektedir. C. Czerny (17911857) gibi dönemin üst düzey saygı gören bir figürün de aralarında bulunduğu pek

1 Michael Thomas Roeder, The History Of Concerto, Amadeus Press, Portland 2003, s. 23

2 Ulrich Michels ve Gunter Vogel, Müzik Atlası, Alfa Müzik, İstanbul 2015, s. 439 
çok bestecinin, piyanistlerin teknik becerilerini geliștirebilmeleri için besteledikleri çalıșma parçalarının (etüt) çeșitliliği, dönem müziğinin icra edilebilmesi için müzisyenlerin ulașması gereken teknik yeterliklere dair bizlere bazı ipuçları sunmaktadır. Bu tip çalıșma parçalarının ulașmıș olduğu en yüksek bașarı noktalarından biri olarak da F. Chopin'in (op. 10 ve op. 25) etütlerini gösterebilmekteyiz. ${ }^{3}$
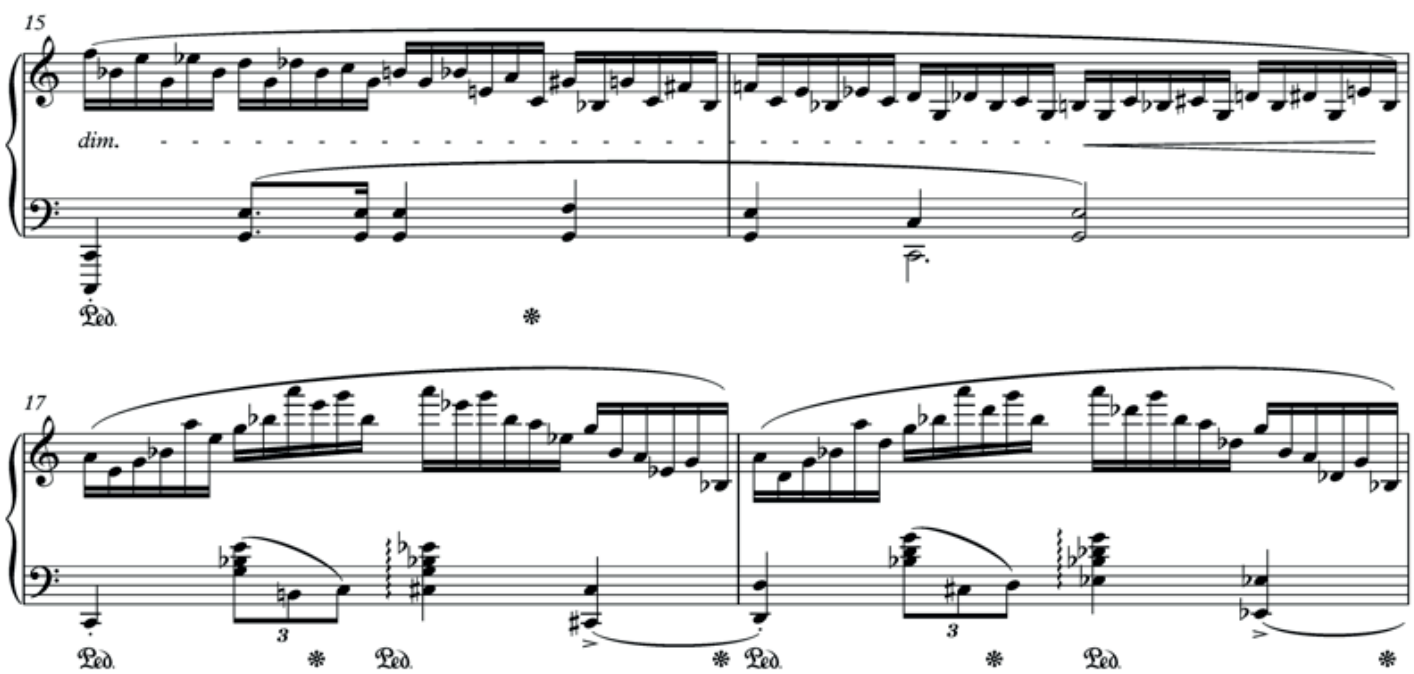

Şekil 2. F. Chopin, La minör Etüt, Op. 25 No. 12

Romantik Dönem piyano literatürü her ne kadar yer yer yalın bir müzikal dokuyla örülmüş olsa da, daha geniş bir perspektiften bakıldığında müzik dilinin genel olarak kendinden önce gelen Klasik Dönem'e göre daha yoğun ve karmașık bir çerçevede șekillendirildiğini söyleyebilmekteyiz. Piyano literatürünün ana iskeletini olușturan bu karmașık dokunun izdüșümlerini dönemin orkestral müzik literatüründe de gözlemlenebilmektedir.

19. yüzyılın son çeyreği itibariyle Chopin, Liszt, Schumann, Brahms gibi Romantik Dönem'in öne çıkan bestecilerin eserleri literatürde çoktan yerini almaya bașlamıștı. İcra tekniğinde böylesine bir sıçrama yașandığı bir dönemde yapılan bu armonizasyonların
(Guatelli'nin çalıșmaları), çağdaşları ile karșılaștırıldığında, içinde bulunduğu çağın piyano yazısının üslup ve teknik kimliğini taşıdığını söylememiz pek mümkün görünmemektedir. Romantik Dönem piyano müzik dilinin teknik ve estetik perspektifinde buluștuğu ortak paydalarının bu iki armonizasyonda da rastlanamaması gözlerimizi diğer dönemlere çevirmemize neden olmaktadır. İçinde bulunduğu çağın müzik yazım karakterlerini bünyesinde barındırmayan bu eserlerin dokusal yapısının izlerini, Barok ve erken Klasik Dönem eserlerinde rastlayabilmekteyiz. Soprano hattında bulunan melodik yapıya eșlik eden ikinci bölge (bas hattı), bir

3 Ulrich Michels ve Gunter Vogel, Müzik Atlası, Alfa Müzik, İstanbul 2015, s. 443 
melodi gibi davranırken aynı zamanda akor seslerinin arasında dolaşarak bir eșlik karakterini görevini üstlenmektedir. Barok Dönem'de çok sık rastlanan bu stil, aynı zamanda W. A. Mozart'ın (17561791) çocukluk yıllarında bestelemiş olduğu eserlerde de görülebilmektedir.

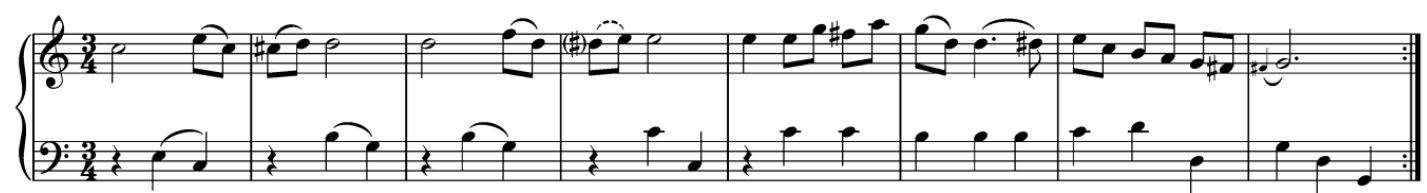

Şekil 3. W. A. Mozart, Minuet K. 6 (Do Majör)

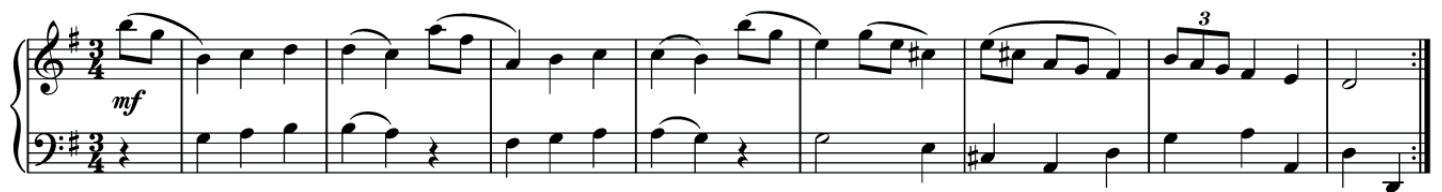

Şekil 4. W. A. Mozart, Minuet K. 1e (Sol Majör)

Akorların blok șeklinde kullanımından kaçınılmış olması, Guatelli'nin incelenen armonizasyonlarında göze çarpan bir diğer nokta olarak karșımıza çıkmaktadır. Bestecinin yazmıș olduğu Osmaniye Marșı, Aziziye Marșı ve Osmanlı Sergi Marșı'nın müzik dilleri ve dokuları incelendiğinde, Romantik Dönem literatürü ile bu yönde bir paralellik gözlemlenebilmektedir. $\mathrm{Bu}$ marșlarda akorların blok halde kullanılması, ortak bir payda olarak değerlendirilebilir. Romantik Dönem'de bestelenmiş operalarda, piyano eserlerinde ve diğer müzik formlarında benzer bir anlatım dilinin aynı çağdaki diğer besteciler tarafından da benimsediğini söyleyebiliriz.

\section{Yüzyıl Osmanlı Kültuiründe Batı Müziği Ve Piyanonun Yeri}

Batı müziğinin Osmanlı kültürü ile teması çoğunlukla diğerülkeveimparatorluklarla yapılan resmî ilișkiler çerçevesinde ve kısıtlı bir alanda gerçekleșmiștir. II. Mahmud döneminde Mehterhane'nin kaldırılıp yerine Musika-i Hümâyûn ve onun çatısı altında Batı müziği eksenli bir bandonun kurulması ile, Osmanlı kültüründe Batı müziğine yönelmenin belki de o tarihe kadar en kararlı adımı atılmış oldu. Sultan II. Mahmud tarafından kurulan bu bandonun başına, dönemin en tanınmıș bestecilerinden biri olan Gaetano Donizetti'nin (17971848) ağabeyi Giuseppe Donizetti (17881856) getirildi. İstanbul'daki kariyeri boyunca müziğin farklı alanlarında ve devletin farklı katmanlarında sayısız katkı sunan İtalyan müzik insanı, Batı müziği stilinde bestelediği eserleri bu kurumun repertuvarına kazandırdı ve ülkenin müzik kültüründeki köklü değișimlerin önemli bir sembolü olarak öne çıktı. "Osmanlı İmparatorluğu muzikalarının genel eğitmeni" unvanı ile Sardunya Krallığı tarafından İstanbul'a gönderilen Donizetti, gerek eğitmenliği, gerek șefliği, gerek besteciliği ile kuruma büyük katkılar sağlamıș ve kazandırdığı niteliklerin bir sonucu olarak, bandonun devletin pek çok etkinliğinde aktif olarak yer alabilmesi noktasında rol üstlenmiștir. Bu dönemde Batı müziğinin Osmanlı kültüründeki diğer bir etkisi ise sahne sanatlarında yașanmaktaydı. Batılılașma hareketinin kurumsal alanda Musika-i Hümâyûn ile bașladığını söyleyebilmekteyiz. Bu bașlangıç 
getirdiği rüzgarın etkisiyle, bir süre sonra İstanbul'da opera, operet ve müzikli oyun gibi sahne performanslarının sergilendiği tiyatrolar faaliyete girmeye bașlamıșlardı. Bugün belki de bu kurumlardan en çok bilinenlerden biri ise Naum Tiyatrosu'dur (1870’lere kadar etkinliğini sürdürmüștür). İstanbul'da etkin bir Batı müziği hayatının sürdürülmesinde rol sahibi bu tiyatrolarda Verdi, Donizetti gibi dönemin ünlü bestecilerin operaları sahnelenmekteydi. ${ }^{4}$ Sultan Abdülmecid'in de desteklediğini bildiğimiz bu faaliyetler Osmanlı'nın kültür politikalarının geçirdiği evrimi ve bu değişim sürecinin gündelik hayattaki yansımaları konusunda bizlere bazı ipuçları sunmaktadır.

Sultan Abdülmecid'in hükümdarlığında Batı müziği, etkisini Osmanlı sarayında kendine daha geniș bir alanda hissettirmeye bașlamıștı. Piyano çalan Sultan Abdülmecid'in, bu noktada en azından padișahlık seviyesinde Batı müziği eksenli eğitim alan ve piyano çalan ilk padișah olduğu görülebilmektedir. Kuruluşundan sonra gelișimini Abdülmecid döneminde sürdüren Musika-i Hümâyûn'un bünyesinde görevini sürdüren Donizetti ve Necib Paşa gibi dönemin önemli müzik figürlerin de aralarında bulunduğu eğitmenler sarayda dersler vermekteydi. Batı müziğine olan ilginin artması ile piyano da pek çok diğer çalgı gibi, saray bünyesinde kendine yer buldu. ${ }^{5}$ Sultan Abdülmecid'in Batı müziğine verdiği önemin yansımaları aynı zamanda kendi ailesinin fertlerinde de gözlemlenebilmektedir. Sultan'ın kızlarından Refia Sultan (1842-1880), T. Romana isimli bir İtalyan hocadan piyano dersleri alırken, Sultanın diğer bir kızı olan Fatma Sultan (1840-1884) ise Guatelli Pașa ile piyano eğitimini sürdürmüștür. ${ }^{6}$ Müzik sanatının hanedan üyeleri arasında yoğun bir ilgi gördügüunü ve hem Batı müziği hem de Türk müziği alanlarında eğitimlerini sürdürdükleri bilinmektedir. Özellikle Sultan Abdülmecid döneminden itibaren bu ilginin Batı müziği alanında da yaygın bir kabul gördüğünü söyleyebilmekteyiz. ${ }^{7}$

“Özellikle Sultan Abdülmecid' den itibaren başlayan piyano eğitimine karșı ilginin, Sultan II. Abdülhamid döneminde daha da arttığı, bunun sonucunda saraya birçok piyanonun satın alındığı bilinmektedir. Piyanolar hanedan mensuplarının yașadığı veya ziyaret ettiği çeșitli saray, kasır ve köșklerde kullanılmıștır. Bugün de İstanbul ve Yalova'daki çeșitli yapılarda korunmakta olan bu çalgılar, hanedanın Batı müziğine olan ilgisinin kanıtı olarak göze çarpmaktadır"8.

1861 yılında tahta çıkan Sultan Abdülaziz'in müziğe olan yaklașımı, ağabeyi Sultan Abdülmecid'den daha farklı bir desende varlığını sürdürmüștür. Ağabeyinin aksine Türk müziğine daha yakın bir noktada duran Sultan, saray ve çevresinde önceleri Batı müziğ etkinliklerine ağabeyi kadar önem vermediği görülmektedir. ${ }^{9}$ Sultanın ailesinin de Türk müziğine, Batı müziğinden daha yakın olduğunu ve

4 Tanzimat'tan Cumhuriyet'e Türkiye Ansiklopedisi 5. Cilt, Bülent Aksoy, İletișim Yayınları, İstanbul 1985, "Tanzimat'tan Cumhuriyet'e Musıki ve Batıılıșma" maddesi

5 Selçuk Alimdar, Osmanlı'da Batı Müziği, Türkiye iş Bankası Kültür Yayınları, İstanbul 2016, s. 10

6 Selçuk Alimdar, age., s. 12

7 Sultan III. Selim'den itibaren hanedanın müziğe olan ilgisinin daha iyi anlașlabilmesine katkı sağlayan bir liste, Selçuk Alimdar'ın Osmanlı'da Batı Müziği isimli kitabının 7. Sayfasında yer verilmiştir.

8 Yonca Karul İlyas, Piyanonun Osmantı'daki Serüveni, Nobel Yayın, Ankara 2020, s. 13

9 Evren Kutlay Baydar, “19. Yüzyıl Padișahlarının Müzik Politikalarından Kesitler", YDÜ Sosyal Bilimler Dergisi, 4/1 (2011), s. 103 
aile bireylerinin kanun, tanbur, kemençe ve ud, gibi çalgılara ilgi duyduğunu görebilmekteyiz. ${ }^{10}$ Türk müziğine olan ilgisine paralel olarak ayrı bir kulvarda Batı müziği alanında donanımını geliștiren Sultan Abdülaziz, (elyazmalarının mevcut olamaması sebebiyle otantikliğinden tam olarak emin olamadığımız) Batı müziği stilinde eserler besteledi (Invitation à la Valse, La Gondolle Barcarolle, La harbe Caprice ve Polka). Bu bilgilerin ışığında Sultanın belirli bir seviyede Batı müziği donanımına sahip olduğunu düşünülmektedir. ${ }^{11}$ Dönemin Batı müziği alanındaki kurumsal temsilcisi olan Musika-i Hümâyûn'da ser-muallim olarak çalıșmalarını sürdüren Guatelli'den Batı müziği dersleri alan Sultanın, 03 Nisan 1863 yılında bașlayan Mısır seyahatinde beraberinde Guatelli'yi de alması, Guatelli ve Batı müziğine verdiği önemin bir yansıması olarak görülebilmektedir. Saltanatının ilk yıllarında Musika-i Hümâyûn' daki Batı müziği bölümlerinden uzaklaștırdığı müzisyenler nedeniyle itham edilen Sultanın, bu ve daha sonradan gerçekleștireceği Avrupa seyahatlerinde Guatelli'yi beraberinde götürmesi, Türk müziğine gösterdiği ilgisinin Batı müziği alanına da yayılmış olduğunun bir göstergesi olarak yorumlanabilmesi mümkündür. ${ }^{12}$

"Abdülaziz Efendi her zaman gelenekçi Müslüman camiasına mensup olarak görülmektedir. Ancak așağıda vereceğimiz örnek onun Hristiyan dünyasına karșı da toleranslı olduğunu göstermektir. Eski sultanın bando șefi Sinyor Guatelli Abdülaziz Efendi'ye periyodik olarak ders vermekteydi. Onun saraya çağıran mektup eline ulaștıktan bir gün sonra, kabul esnasında bu ziyareti neden gerçekleștirdiğini soran sultana, size piyanoda ders vermek için geldim diye cevap verdi. Bu sırada sultan sözünü kesti: 'Biliyorsun pașalar müzik dersi vermeye tenezzül etmezler'. Bu anda Sinyor Guatelli, Marko Paşa'nın rütbesi olan 'Siva Pașa'13 rütbesine yükseltildiğini öğrenmiș oluyordu"14

Sultan Abdülaziz döneminin devamında, Sultan V. Murad veSultan II. Abdülhamid' in de babaları Sultan Abdülmecid gibi Batı müziğine karșı yoğun ilgisinin izdüșümlerini gözlemleyebilmekteyiz. Sultan V. Murad'ın iyi seviyede piyano çaldığı ve kompozisyon alanında diğer padișahlara göre daha fazla eser vermesi ile bu noktada öne çıktığını söyleyebilmekteyiz.

Şehzadeliği sırasında Guatelli'den solfej ve piyano dersleri alan Sultan, vals, polka gibi Avrupa dans stillerinde/formlarında kaleme aldığı kompozisyonlarına paralel olarak askeri marșların bestelenmesi konusuna da ilgi duymuș ve bu alanda da eserler vermiștir. Sultanın kızları Fehime ve Hatice Sultanların da babaları gibi, besteciliğe ilgi duydukları ve bașta marş olmak üzere, Batı müziğinin diğer formlarında da eser bestelediklerini bilmekteyiz. ${ }^{15}$ Yaklașık üç ay gibi kısa bir sürede tahtta kalabilmiş olan Sultan v. Murad, Osmanlı hanedanlığında Batı müziğinin benimsenip yaşatılması konusunda çok değerli katkılar sunduğu șüphesizdir.

\footnotetext{
10 Emre Aracı, Kayıp Seslerin İzinde, Yapı Kredi Yayınları, İstanbul 2011, s. 7

11 Hikmet Toker, Elhan-1 Aziz Sultan Abdülaziz Döneminde Sarayda Mûsikî, TBMM Milli Saraylar 2016,

s. 119

12 Hikmet Toker, age., s. 86

13 Hikmet Toker burada kastedilenin Liva Pașa olması gerektiğinin altını çizmektedir

14 The Bath Chronicle, “Turkey”, 11 Temmuz 1861 Perșembe, s. 6

15 Evren Kutlay Baydar, age., s. 104
} 
Sultan Abdülhamid'in 1876 yılında tahta geçmesinin ardından Musika-i Hümâyûn ve saray çevresinde Batı müziğinin ağırlığı artmaya bașladı. Sultan Abdülaziz döneminde Türk müziğinin öne çıkması ile bir miktar etkinliğini yitiren Batı müziği, yine Guatelli'den ders alan Sultan Abdülhamid'in tahta çıkması ile beraber, kurumsal alanda kendine daha çok yer bulmaya bașladığını söyleyebilmekteyiz. Haremdeki kadınlar orkestrasının ve harem bandosunun Abdülhamid döneminde tekrar canlandırılması, sultanın Batı müziğine verdiği önemin bir yansıması olarak yorumlanabilir. ${ }^{16}$ Kendisi de iyi bir piyanist olan Sultan, bu kültürün kendi aile fertlerini tarafından da sürdürülmesini istemiş ve bunun sonucu kızlarından Zekiye Sultan (piyano), Naime Sultan (piyano), Naile Sultan (piyano), Şadiye Sultan (piyano, arp, tanbur ve ud), Ayșe Sultan (piyano), Refia Sultan (piyano); ve oğullarından Mehmet Selim Efendi (piyano), Abdülkadir Efendi (piyano ve keman), Ahmet Nuri Efendi (piyano), M. Burhaneddin Efendi (piyano), Abdulrahim Hayri Efendi (piyano), Ahmed Nureddin Efendi (piyano) ve Mehmet Abid Efendi (piyano) belirtilen çalgılara yönlendirilmișlerdir. ${ }^{17}$

\section{Callisto Guatelli}

İtalya'nın Parma șehrinde doğan Callisto Guatelli $\quad(1818-1900)^{18}$, meslektașı Giuseppe Donizetti (1788-1856) ile beraber Osmanlı Devleti'nin hem kurumsal yapilanması içinde hem de gündelik hayata yansıyan müzik yașamına çok büyük katkılar sunmuştur. Bu iki İtalyan müzik insanı, hem müzisyenliği, hem șefliği, hem eğitmenliği, hem de bestecilik donanımları ile devletin pek çok katmanında ve alanında kalıcı izler bırakmıștır. II. Mahmud, Abdülmecid, Abdülaziz, V. Murad ve II. Abdülhamid dönemlerini kapsayan bir sürede görevini sürdüren ve Osmanlı müzik politikalarının bir yansıması olarak görülebilen bu iki figür, 1828'den 1900 (her ikisinin toplam görev süresi) yılına uzanan bir zaman diliminde görevlerini sürdürmüş ve Paşalık mertebesine kadar yükselmișlerdir. ${ }^{19} \quad$ Osmanlı'nın ikinci İtalyan maestrosu Guatelli, 1830'da doğduğu șehrin müzik okulunda Francesco Hiserich'ten (1772-1851) kontrbas ve Antonio Cesari'den (1797-1853) șan dersleri aldı. 1838 yılında eğitimini bașariyla tamamlayan ve mezun olan Guatelli, İtalya'da koro șefi olarak görev çalıșmalarını sürdürdü. 1845'te Naum tiyatrosu opera bölümünün bașında çalıșmaya başladı. ${ }^{20}$

1856 yılında Donizetti Paşa'nın hayatını kaybetmesinin ardından Callisto Guatelli Musika-i Hümâyûn'da çalıșmalarına bașladı, ancak bugün net olarak bilinmeyen bir nedenden dolayı, görevinden kısa bir süre sonra ayrıldı. Sultan Abdülaziz'in tahta geçmesi ile Guatelli'nin Osmanlı Devletin'deki görev serüveninin bir sonraki perdesine geçtiğini görebilmekteyiz. Abdülaziz döneminin hemen başında yapılan atama ile meslektașı Donizetti'den sonra ikinci bir İtalyan müzik insanı, müzisyenlik, șeflik, eğitmenlik ve bestecilik alanlarında, devlete büyük katkılar sunmaya devam etti. Batı müziği formalarında vermiș olduğu eserlerin yanı sıra, dönemin tanınmıș makamsal

16 Evren Kutlay Baydar, age., s. 104

17 Selçuk Alimdar, age., s. 9

18 Emre Aracı, Kayıp Seslerin İzinde isimli kitabında, Guatelli'nin doğum tarihini 1818 olarak belirtir. Bu bilgiyi Feriköy Katolik Latin Mezarlığındaki mezar tașına dayandırmaktadır (Literatürde genellikle 1920 olarak yazılır)

19 Emre Aracl, age., s 393, s. 395

20 Selçuk Alimdar, age., s. 90 
yapıtlarını armonize etmiş ve bunların İstanbul'un önemli nota yayımcısı Hacı Emin Efendi tarafından basılıp müzik hayatına kazandırılmasını sağlamıștır. ${ }^{21}$ Dönemin önemli bestecilerinden bir olan Gaetano Donizetti'nin ağabeyi olan Giuseppe Donizetti'den sonra Musika-i Hümâyûn'da görevi üstlenen Guatelli'nin, tanınmıș bir soyadı tașıyan bir müzik figüründen sonra böylesine önemli bir konuma getirilmiș olmanın baskısını omuzlarında hissetmiș olabileceğini tahmin edebilmekteyiz 0 dönemde Avrupa'nın müzik dünyasında öne çlkan figürleri ve Donizetti ile karșılaştıııldığında, Guatelli'nin sahip olduğu müzik donanımının bir İmparatorluğun en üst seviyesinde böylesi önemli bir görev için yeterli olup olmadığını tam olarak değerlendirebilmemiz bugün için pek mümkün görünmemektedir. Mahmut. R. Gazimihal Türk Askerî Muzikaları Tarihi isimli kitabında șu ifadeye yer vermektedir: "Abdülhamid, onun (Guatelli'nin) musikideki kifayetsizliğini bilmekle beraber, hoș kullanarak emektarlığına riayet göstermiștir."22 Sultan Abdülhamid'in bu düșüncesini iki farklı șekilde yorumlayabilmemiz mümkün görünmektedir. 1- Guatelli, uzun yıllar boyunca Devletin farklı katmanlarında emek vermiș ve ülkenin Batı müziği kültürünün gelișiminde büyük katkı sağlamıș olsa da, böyle bir pozisyon için yeterli müzik donanımına sahip değildi. 2- Önceki dönemlerde gösterdiği performansı, belki de yașı sebebiyle bu dönemde aynı oranda sergileyemedi. H. Toker, Elhan- ו Aziz isimli kitabında, Gazimihal'ın șu sözlerine yer vermektedir. "Batının Alberti Basso'su ve Murkys gibi en basit akopanyıman prosedelerini andıran kolay oktavlamalarla ahenklediği peșrev ve șarkıları piyano için bastırmış öğretmeye başlamıștır. Zamanın modasına uygun olarak yazdığ sekiz on parçası da basılmıștır. Bütün bunlar gözden geçirilince kendisini gençken kuvvetli bir konservatuar tahsili görmemiş olduğu, pratikten kumpanya maestroluğuna yükselebilmiş istidâtlardan sayılması gerektiği, ve hatta neden dolayı Abdülmecid devrinde pek kısa bir tecrübeden sonra yerini bașka bir İtalyan'a terk ettiği kolaylıkla istinat edilebilir."23 Guatelli'nin müzik becerilerinin ve eğitimci olarak kuruma sağladığı katkıların günümüz noktasından bakıldığında tam olarak tespit edilebilmesi ve ölçülebilmesi pek mümkün görünmemektedir, ancak diğer yandan, kompozisyonlarının ve düzenlemelerinin analiz edilebilmesinin mümkün olması sebebiyle, bu alanda sağladığı katkıları daha objektif bir perspektiften değerlendirebilme şansını yakalayabilmekteyiz.

\section{Romantik Dönem'in diğer tanınmıș} bestecileri kadar (hem miktar, hem hacim, hem de üzerine yoğunlașılan müzik formlarının çeșitliliği bakımından) eser üretmemiș olduğu görebilen Guatelli'nin yaratıcılığında, marș formunun önem kazandığını söyleyebiliriz. Bu estetik çerçevesinde bestelenmiș olan Mecidiye Marșı ve Hymne (Sultan Abdülmecid'e ithaf edilmiștir), Osmaniye Marșı ve resmî marș olarak da kabul edilen Aziziye Marșı (Sultan Abdülaziz'e ithaf edilmiștir), Hamidiye Marșı ve Yıldız Marșı (Sultan II. Abdülhamid'e ithaf edilmiștir), Osmanlı Sergi Marșı (Sadrazam Mehmed Fuad Pașa'ya ithaf edilmiștir), Șefkat Marșı, Șevket Marșı ve Șark Üvertürü gibi yapıtlar, Guatelli'nin yaratıcılığında öne çıkmaktadır. ${ }^{24}$ Özellikle 19. yüzyılın ikinci yarısında Avrupa'daki besteciler arasında

21 Hikmet Toker, age., s. 293, s. 297

22 Mahmut. R. Gazimihal, Türk Askerî Muzikaları Tarihi, Doğu Kütüphanesi, İstanbul 2019, s. 83

23 Hikmet Toker, age., s. 296

24 Selçuk Alimdar, age., s. 92 
da oldukça popüler olan marş formunda bestelenmiş olan bu yapitlara artmıș ikili aralığının belki de bilinçli olarak eklenmesiyle ses örgüsüne makamsal bir renk kazandırılması amaçlanmış olabilir. Bu ve bunun gibi makamsal elementlerin müziğe eklenmesi ile beraber Doğu-Batı kültürlerinin izlerini tașiyan melez bir karakterin yaratılmasının hedeflenmiş, olabileceğini söyleyebiliriz. Elbette Guatelli'nin İstanbul'da geçirdiği zaman göz önünde bulundurulduğunda, melez bir müzik üretme çabasının sadece artmış ikili aralığına indirmek doğru olmayacaktır. Hem kurumsal hem de gündelik hayatta, makam müziği ile yakın temaslar kurmuș olabileceğini tahmin edebilmekteyiz. Bu nedenle bestelemiş olduğu eserlerin yapısında makamsal ögelerin yer alması, bilinçli bir seçimin ötesinde doğal bir bestecilik refleksi olarak da yorumlanabilmelidir. Guatelli, askerî müzik karakteri tașıyan eserlere ek olarak, "Arie Nazionali e Canti Popolari Orientali" isimli, dönemin popüler Türk müziği eserlerinde ilham alarak bestelediği ve İstanbul'da basılan bir piyano albümünün yanı sıra Türk müziği repertuvarından seçilen makamsal eserlerin armonize edilmesiyle olușturulan piyano parçaları gibi farklı perspektifte yapitlar da bestelemiștir. Bu armonizasyonlar sadece Guatelli'nin bireysel fantezi dünyasının bir yansıması olmakla kalmayıp, aynı zamanda dönemin müzik eğilimleri ve kültürel dokusu hakkında bizlere bazı ipuçları sunmaktadır. Günümüzde de hala geçerliliğini koruyan "müzikte yerellik ve evrensellik" meselesinin, Osmanlı'nın kurumsal ve gündelik hayatının farklı katmanlarında da benzer bir șekilde gündemde olduğunu tahmin edebilmekteyiz. Musika-i Hümâyûn'un yapılanması bașta olmak üzere, saray ve çevresinin de Batı müziği ve Türk müziği ikiliği ile biçimlenmiș bir müzik kültürü ile çevrelenmiș olduğunu rahatlıkla söyleyebilmekteyiz. Böyle bir ortamda Guatelli'nin bu armonizasyonları yapmasının ardında yatan olası motivasyonların üçü şu șekilde listelenebilmektedir: a- Sadece yaratıcılık dürtüsü b- Eğitim amaçlı cTicari sebepler. Belirtilen maddelerin farklı oranlarda etki ettiği bir bileșkenin bu durumu hazırlamıș olabileceği gibi, burada belirtilmeyen ve tümüyle bağımsız bașka sebeplerin de bu durumda rol oynamış olma olasılığının bulunması nedeniyle bu așamada kesin bir değerlendirme yapmak pek mümkün görünmemektedir.

\section{Makamların Tonal Sisteme}

\section{Entegre Edilmesi Ve 12 Ses Eșit}

\section{Tamperaman Sistemi}

Tarihsel süreçte, makamsal eserlerin çokseslendirilmesine yönelik yapılan çalıșmaların bir parçası olarak görülebilecek bu armonizasyonlarların, makam-tonalite ekseninde nereye konumlandırılabileceği, bu noktada ele alınmaya çalıșılacaktır.

Batı sanatında Ortaçağ Dönemi ile yolculuğuna bașlayan çokseslilik geleneği, yüzyıllara yayılan bir değișim sürecinden geçerek evrimsel serüvenini sürdürmüștür. Bu gelișime koșut olarak diğer bir kulvarda ise akort sistemleri ve tamperamanların evrimsel sürecini gözlemleyebilmekteyiz. Çokseslilik ile akort sistemlerinin izlediği bu yolda, bu iki ögenin içe geçmiș ve sürekli etkileșim halinde olduğunu görebilmekteyiz. Bu elemanlardan birinin değișimi, bir diğerinin de değișmesine neden olabilmektedir. $\mathrm{Bu}$ tip etkileșim senaryolarından bir 
tanesinin bas rol karakteri ise "12 ses eșit tamperaman" olarak isimlendirilen ve bir oktavın eșit 12 parçaya bölünmesi ile elde edilen akort sistemdir. Rönesans müziğinde özellikle perdeli çalgılarda kullanımına rastladığımız sistemin, Barok Dönem ile beraber yaygınlașmaya bașlamasıyla devam eden serüveni, bugün neredeyse bir standart haline gelmesiyle sonuçlanmıștır. Tarihsel süreçte kullanılan pek çok akort sistemi ve tamperamandan yalnızca biri olan “12 ses eșit tamperaman” sisteminin yaygınlașmasının pek çok olası sebepleri arasında belki de en önemlisi, tonal müzikte yașanan gelișmeler sonucu bestecilerin aynı eser içinde pek çok tonu ziyaret etme (modülasyon/geçki) ve parçaları farklı tonlarda icra etme (tranzpozisyon/göçürme) ihtiyaçlarının gündeme gelmesidir. Bunun dișında örneğin org, klavsen gibi tușlu bir çalgıda farklı tonda yazılmış pek çok eserin çalınabilmesinin mümkün kılan sistem, tonal müziğin sınırlarını genișledikçe daha avantajlı bir araca dönüșsmüștür. ${ }^{25}$ Buyeni sistem farklı tonlarda bestelenmiş pek çok eserin tek bir çalgı üzerinde icra edilebilme özgürlüğü sunduysa da, bu olanakların karșılığında bazı noktalarda taviz verilmek durumunda kalınmıștır. Diğer sistemlerde daha konsonant tınlayan bazı akor ya da aralıkların bu sistemde aynı seviyede konsonant tınlamamaması, bu sistemin en önemli dezavantajlarından biri olarak görülmektedir (disonant ve konsonant kavramlarının bilimsel bir tanımı olsa $\mathrm{da}$, günün sonunda insanlar tarafından farklı algılanabildiğinin bu noktada altı çizilmesinde fayda görülmektedir). Bu nedenle bestelenmiş bir eser, farklı akort sistemlerinde/tamperamanda icra edildiğinde görece büyük tınısal farklılıklar oluşabilmektedir. ${ }^{26}$
Avrupa merkezli çokseslilik geleneğinin doğup gelișme sürecinde, tonalite/ modalite kavramlarının, ezgisel dilin dikey organizasyona etkisinin, akort sistemlerinin/tamperamanların ve çalgısal müziğin yaygınlașması gibi sayısız faktörün etkisi olduğunu söyleyebiliriz. Tarihsel süreçte bu değișkenlerin geçirdikleri evrim süreci ile birbirlerini etkilediğini ve nihayetinde, her dönemin kendi müzik estetiği çerçevesinde ezgi ya da ezgilerin çokseslilik örgüsü içinde optimum bir uyum çerçevesinde buluștuğunu söyleyebilmekteyiz. Diğer yandan, yukarıda ifade edilen böylesine uzun bir süreçten farklı olarak, makamsal müziğimizin çokseslendirilme serüveninin içerisinde, melodi ile çoksesliliği olușturan ögeler arasında oluşabilecek böylesine bir bağın tarihsel süreç içinde gelişip 19. yüzyılın son çeyreğine tașındığını söylemek pek mümkün değildir. Bu nedenle incelenen armonizasyonlarda ezgisel yapı ile çokseslendirme yöntemleri arasında bazı sorunlu alanların oluștuğunu gözlemleyebilmekteyiz. Guatelli'nin bu parçalarında, armonize edilen ezginin doğal ses örgüsünün gözetildiğini ve çokseslendirme yaklaşımının bu hassasiyete göre șekillendirildiğini söylemek çok gerçekçi olmayacaktır. Bunun öncelikli sebebinin tuşlarının sayısı sebebiyle bir oktavın en fazla 12'ye bölünebilmesine izin veren ve geleneksel olarak "12 ses eșit tamperaman" sisteminde akort edilen piyanonun yapısal özellikleri olduğunu söyleyebiliriz. $\mathrm{Bu}$ nedenle makam müziğimizin en

25 Onur Șenel, “Müzikte Mükemmelliğin Göreceliği: Akort Sistemlerinin Evrimi ve Eșit Tampere Sistemin Yükselișī”, Uluslararası Sosyal Araștırmalar Dergisi, $14 / 76$ (2021), s. 361

26 Early Music Sources, "Temperaments-What You Should Know”, video, erișim 15 Nisan 2021, https:// www. youtube.com/watch?v=TgwaiEKnMTQ 
karakteristik özelliklerinden biri olan ses sistemi nedeniyle, bugün makamsal yapıdaki eserlerin, standart bir șekilde akort edilmiş bir piyano ile icrası, öze uygunluk perspektifinde pek mümkün görünmemektedir. Ușşak, Hicaz, Hüzzam, Saba gibi makamların gövdesini olușturan ve " 12 ses eșit tamperaman" ile icra edilemeyecek perdelerin bulunması, piyano çalgısını makamsal müziğin icra edilmesi için -en azından günümüzdeki hali ile- uygun bir aday olarak öne çıkarmamaktadır. Bu nedenle makamsal müziğin piyano ile icra edilmesi gereken durumlarda, belki de makamların en karakteristik özelliklerinden taviz verilmesi gerekmektedir. Bu nedenle bu tip uyarlamalarda/ armonizasyonlarda, makamların renk paleti radikal bir șekilde farklılaștığı için, tınısal sonucun "makamsal" olarak tanımlanmasındansa, ele alınan makamın "12 ses eșit tamperaman" sistemindeki bir yansıması șeklinde ifade edilmesi daha doğru olacaktır. Incelenen bu armonizasyonlardaki eserlerin orijinallerinin Ușşak ve Hicaz makamlarında olduğu göz önünde bulundurulduğunda, yașanan değișimin büyüklüğü nedeniyle bu makamların gelenekselleșmiș makamsal tınılarından uzaklaștığını söyleyebiliriz. Segâh perdesinin icrasının mümkün olmadığı durumlarda örneğin Ușşak makamının tınısal boyutta diğer makamlarla arasındaki karakteristik farklarının azaldığını söyleyebilmekteyiz. Bu asimilasyon nedeni ile makamların ses organizasyonlarının tonal müziğe doğru bir adım yaklaştığını söylemek çok yanlıș olmayacaktır. Ușșak makamının piyano ile icrası sonucunda, makamsal kimliğinden uzaklașıp tonal bir kostüm ile kușatılabilmesi mümkün olabilmektedir. Guatelli'nin yaptığı da tam olarak budur. Eserlerin orijinal ses örgüsünü dikkate almadan, onları piyano üzerinde icrası ile edindikleri yeni kimlikleri ile onları Re Minör ve La Minör gibi tonların çerçevesinde yeni kimlikleriyle bulușturmasını ve bu tonlara entegre etmeye yönelik çabalarını gözlemleyebilmekteyiz. Makamsal eserler, tonal müziğin estetik kuralları gözetilerek çokseslendirilmiş ve onlara yeni bir kültürel kimlik kazandırılmıștır.

\section{Hicaz Ve Ușşak Makamların Tonal Çerçevede Ele Alınması}

Hicaz ve Ușșak makamında bestelenmiş bir eserin piyano ile icrasında karșılașabileceğimiz ilk ve belki de en önemli sorun, makamları olușturan bazı perdelerin piyano ile icra edilememesi olacaktır. Gerekli perdelerin noksanlığı her iki makamın da karakteristik tınısal özelliklerini yitirmesine ve geleneksel icralardan alıșık olduğumuz makam kimliğinden uzaklașmasına neden olmaktadır. Bu tür bir icra pratiğinde, her ne kadar iki makamın da özünden uzaklașıp farklı bir karaktere dönüșmesi kaçınılmaz olsa da, bu problemin iki makam için eșit derecede geçerli olmayabileceğini ve bu düșüncenin de yardımıyla Guetelli'nin izlediği -ya da izlemediği- yolu biraz daha iyi anlayabilmemiz mümkün olabilecektir. ilk etapta Hicaz makamındaki perdelerin Ușșak makamına göre "12 ses eșit tamperaman" sistemi ile daha az ortak notaya sahip olduğunu görebilmekteyiz. Piyanoda icra edilen bir Hicaz eserin bu asimilasyona rağmen hala Hicaz kimliğini kısmen koruyabildiği söylemek mümkündür. Olușturulan yeni ses örgüsünün, yitirdiği tınısal palete rağmen, hala Hicaz makamında olduğu anlaşılabilmektedir. Diğer taraftan Ușşak makamı ise özellikle Segâh perdesini 
kaybetmesiyle, Buselik gibi bir diğer makam ile benzeșmeye bașlar. Bunun sonucu olarak bu makamları birbirinden ayırt edebilmemiz güçleșmektedir. Bu nedenle Hicaz makamında yazılan bir eserin armonizasyonunun yapılması -tartışmaya açık olsa da- bir miktar daha avantajlı olabilmektedir.

Guetelli'nin bu iki armonizasyonundaki en ilgi çekici noktalardan biri diğeri ise, eserlerin karar notalarını tonal sisteme uydurabilme çabalarının sonucu olarak farklı perdelere taşınmıș olmasıdır. Makam müziğimizde perdelerin mutlak frekans karşılığı olmaması sebebiyle "Do, Re, Mi" șeklinde isimlendirilmesinin bazı sakıncalar olsa da, burada incelenen örnek eserler piyano için yazıldığı için, makamlardaki perdelerin mutlak bir frekansa bağlanmış olduğu görülebilmektedir. $\mathrm{Bu}$ nedenle bu noktadan sonra perde isimleri ile beraber "Do, Re, Mi" șeklinde nota isimlerinin kullanılması, eserlerin melez yapısından dolayı gerekli görülmüștür.

Asım Bey'e ait Hicaz şarkının (TRT arşiv no. 11633-Eserin arșivdeki notası ile armonizasyonda kullanılan versiyonu arasında büyük oranda farklılıklar gözlemlenmektedir) La notası (Dügâh perdesi) ekseninde yazıldığı görülebilmekte ve bu nedenle parçanın genel tonal merkezinin La notası üzerine kurgulanmış olmasını beklemek akıllara gelebilecek belki de ilk olasılık olacaktır. $\mathrm{Ne}$ de olsa makamsal eksen La notası üzerine yapılandırılmıștır (geleneksel makam icra pratiğinde örneğin bir eser La notası ekseninde yazılmıș bile olsa, icracı o eseri herhangi bir notadan bașlayarak seslendirebilmektedir, bu nedenle notada La olarak görülen sesin gerçekten 440 $\mathrm{Hz}$ La notasını temsil etmesi gerekmez.
Diğer yandan, bu armonizasyonların piyano için tasarlanması sebebi ile, bu örnekte olduğu gibi La ekseninde yazılan makamsal eser, gerçekten de piyanodaki La sesi $-440 \mathrm{~Hz}$ - ekseninde tınlar). Guatelli bu tip bir yaklașımı benimsemektense, makamsal eserin ekseni La notası olmasına rağmen, armonizasyonu $\mathrm{Re}$ Minör ve Re Majör ekseninde yapmayı tercih ettiği görülebilmektedir. Bu iki tonaliteli yapının ardında yatan sebep, Hicaz makamındaki Eviç perdesinin ( $\mathrm{Fa}$ Diyez), Acem perdesi (Fa) ile dönüşümlü kullanımıdır. Hicaz makamında rastlamaya alıșık olduğumuz bu durumun tonal müzikteki izdüșümü ise eserin genel olarak Re majör ve Re minör arasında salınmasina neden olmasıdır. Hicaz makamında yazılmıș șarkıda Eviç perdesinin ( $\mathrm{Fa}$ Diyez) sıklıkla geldiği bölgelerde Re Majör, Acem perdesinin (Fa) sıklıkla geldi bölgelerde ise Re Minör tonunun renkleri ile armonizasyonun yapıldığını görebilmekteyiz. Eser boyunca tonal bir yelpazenin olanakları çerçevesinde sunulan atmosfer, Koda olarak belirtilen ve aslında bugün ara nağme olarak isimlendirilen kısımdan hemen önce gelen son karar kısmında, Guatelli'nin eseri La notasının ekseninde sonlandırdığını görmekteyiz. Bu noktada aslında Guatelli'nin parçanın makamsal yapısını kavramış olduğunu ve belki de eserin görece en önemli kadansını La notasında yaparak bu parçanın "gerçek" eksenini bilinçli olarak eserin en sonuna saklamıș olabileceğinin, intimaller dahilinde olduğunu söyleyebiliriz.

Ethem Bey'e ait Ușşak şarkının (TRT arșiv no. 2189-Eserin arşivdeki notası ile armonizasyonda kullanılan versiyonu birkaç ayrıntı dıșında oldukça tutarlıdır) armonizasyonunun daha yakından incelenmesiyle, 
Guatelli'nin makam müziği literatürünü çokseslendirme serüveninde izlediği yolun aydınlığa kavușturulabilmesi için bir adım daha atılabilmesi mümkün olabilecektir. Hicaz eserde olduğu gibi, makamın ekseni ile armonizasyonda kullanılan tonal haritanın ekseninde tutarsızlıklar gözlemlenmektedir. Ușşak makamındaki Segâh perdesinin ses kümesinden çıkartılması nedeniyle, geleneksel ahenginden uzaklaștığı görülebilmektedir. Bu renk paletindeki değișim nedeniyle, Ușşak makamının genel olarak böyle bir senaryoda "Eolyan" ve Fa Diyez notasının (Eviç perdesi) daha aktif kullanımıyla "Doryan" modlarını andırabilecek bir platforma taşınabilmesinin mümkün olabileceği bir not olarak buraya düșülmelidir (Bu tip durumlarda makamların dizisel yapısındaki ahenk büyük oranda değișse de seyir ögesinin etkisiyle, modal ve tonal estetik çizgisinden ayrıșmaktadır). $\mathrm{Bu}$ tip bir kimlik değișimi, eserlerin modal bir pencereden ele alınabilmesi olanaklı hale getirse de, Guatelli'nin yine de tonal çizgiden ayrılmamıș olduğunu görebilmekteyiz. Modal bir yaklașım çerçevesinde yapılan armonizasyonun ekseni ile makamsal yapının eksenini aynı notada sabitlenebilmesi mümkün olabilecekken, tonal sistemi armonizasyonların merkezine yerleștirilmesinin ana yol olarak seçilmesi nedeniyle aslında makamsal ekseni/durağı La notası olan eserde, Rast perdesinde (Sol notası) yapılan kalışların Sol Majör ekseninde yorumlandığını görebilmekteyiz. Bu nedenle makamsal eksen aslında La notası iken, tonal perspektifte Sol notasının eksenleștirildiğini görebiliyoruz. Armonizasyonların eksen notaları ve ele alınan orijinal makamsal eserlerin eksenlerin bu denli tutarsız olmasının ardındaki sebep bestecinin fantezi dünyasının bir ürünü mü yoksa tonal müziğe uydurulmaya zorlanması sonucu oluşan bir tablo mu, bunu kesin olarak bilebilmemiz șimdilik pek mümkün görünmemektedir.

\section{Bas Hattında Akorların 3' lüsünün Kullanımı Ve Olası Nedenleri}

Analiziașağıda sunulanarmonizasyonların bas hattında akorların üçlüsüne çok sık yer verilmesi dikkat çekici diğer bir nokta olarak karşımıza çıkmaktadır. Beșli ya da yedili akorların üçlüsünün bas hattında yer almasıyla olușturulan akorların (beșli akorların birinci çevrimi altılı, yedili akorların birinci çevrimi ise beș altı olarak isimlendirilmektedir -farklı terminolojilerde değişik isimlendirmelere rastlanabilir-) kullanım yoğunluğu dikkat çekecek kadar yüksek bir oranda olması sebebiyle, bu kullanımın bilinçli bir tercih olma olasılığının göz ardı edilmemesi gerekmektedir. Akorların birlisinin (kök sesi) ya da üçlüsünün bas hattında yer verilmesi arasında önemli bir tını farklı olușmaktadır. Birlinin bas hattına getirilmesi ile daha güçlü, oturaklı, kullanılan akorun karakterini daha iyi yansıtan bir tını olușturulurken; üçlünün bas hattında kullanılması ile (müzikte tınıların sözcüklerle ifade edilmesinin getirdiği güçlük nedeniyle, bu noktada aktarılmaya çalıșılan düșünce sadece basit bir tasvirden ibarettir. Bireyler kendi öznel algılama sistemlerinde, bu tip tınıları çok daha farklı bir renk paletinde algılıyor olabilirler) daha az oturaklı, akorların karakteristik özelliğini daha az tașıyan, daha kararsız ve daha kaygan bir ses öbeği olușturulmuş olur. Akorların karakteristik tınılarının, bas hattına üçlünün getirilmesi ile görece olarak zayıflaması nedeniyle, bu tip akorların 
kullanımının yüksek oranda tutulduğu bir ses örgüsünde olușturulan sonik yelpazenin tonal müzik tablosundan bir miktaruzaklașıpflulaștığınısöyleyebiliriz. Makamsal bir karaktere sahip olan ezgisel yapının çokseslendirilmesinde kullanılan araçların, tonal müziğin doygun renklerinden seçilmemiș olması Guatelli'nin bilinçli olarak izlemiş olduğu bir rota olabilir. Makamsal müzikten alınıp "12 eșit ton tamperaman” evrenine yerleștirilen ve asimile edilen ezgisel yapıyı, yine tonal müziğin görece yumușatılmış ve flulaștırılmış renk çemberi ile sarmalanmış olması ilgi çekici bir yaklaşım olarak öne çıkmaktadır. $\mathrm{Bu}$ durumda, bu armonizasyonlar tasarlanırken, makam müziği ögelerinden de tonal müzik ögeleriden de değișik oranlarda taviz verilerek ortak bir noktada bulușturulmasının amaçlanmıș olabileceğinin göz ardı edilmemesi gerekmektedir.

\section{Armonik Analizlerde Kullanılan}

Bazı Kısaltmalara Yönelik

Açıklamalar

Armonizasyonların analizinde akor dișı notaları etiketlemek için kullanılan kısaltmaların açılımı ve kısa açıklamaları așağıda sunulmuștur. Müzik literatüründe "akor dıșı notalar/sesler" ya da "armoni dıșı notalar/sesler" olarak da ifade edilebilen bu kompozisyonal araçların kullanımı oldukça yaygındır. Bu konu kontrpuan ile armoni kitaplarının ilgili bölümlerinde kapsamlı bir șekilde ele alınıp açıklanmaktadır. Bu seslerin açıklanabilmesi için, her bir senaryonun ayrı ayrı ele alınıp, bunların uzun açıklama metinleri ve literatürden seçilen örnekler eșliğinde sunulması gerekmektedir. $\mathrm{Bu}$ nedenle, her bir akor dışı notanın ihtiyaç duyduğu kapsamlı açıklama metinlerinin burada sunulmasının pek mümkün olmaması sebebiyle, așağıda verilen birer cümlelik açıklamaların, bilimsel bir nitelemenin ötesinde, kısaltmaların genel olarak nasıl bir uygulamaya ișaret ettiğini açıklamaya yönelik bir amaç taşıdığının belirtilmesinde fayda görülmektedir

Armonizasyonların analizinde kullanılan “Akor Dișı Sesler/armoni dıșı sesler"in kısaltmaları ve kısa açıklamaları:

g Geçiș Notası: İki akor notası arasında bir ya da daha fazla sayıda notanın tek yöne doğu hareketi

ag Aksanlı Geçiş Notası: Kuvvetli zamanda gelen geçiş notası

atg Atlamalı Geçiş Notası: Basamak hareketi ile ilerlemeyen geçiş notası

i İșleme Notası: Bir akor notasının üst ya da alt komşusuna uğrayıp geri gelmesi

ai Aksanlı Ișleme Notası: Kuvvetli zamanda gelen ișleme notası

ati Atlamalı ișleme Notası: Basamak hareketi ile ilerlemeyen ișleme notası

gc Geciktirme: Akor sesinin zamanından daha geç hedefine ulaşması

e Erken Duyurma/Öncelem: Akor sesinin zamanından daha erken hedefine ulașması

a Apojiyatür/Abantı (Appoggiatura): İki tanımı literatürde kullanılmaktadır:

Tanım 1: Güçlü zamanda gelen notanın basamak hareketiyle zayıf zamandaki notaya çözülmesi 
Tanım 2: Atlama ile ulașılan ve güçlü zamanda gelen notanın, basamak hareketi ile așağıya doğru inip çözülmesi

e/a Apojiyatürün erken duyurulması

k Kaçak Nota ya da Kaçış Notası: İki akor notası bağlanırken (genellikle inici ve basamak hareketi ile), ilk nota ikinci notaya ulașmadan önce birinci notanın üst komșusuna uğraması

k/g Geçiș Notasının Kaçak Notası: Geçiş notasına ait kaçak nota

i/e Erken Duyurmanın İșlemesi: Erken duyurulan nota üzerinde yapılan ișleme hareketi

i/g Geçiș Notasının İșlemesi: Bir geçiş notası üzerinde yapılan ișleme hareketi

e/g: Geçiș Notasının Erken Duyurması: Geçiş notasının zamanından önce duyurulması 


\section{HİCAZ ŞARKI}

Orijinal Eser: Giriftzen Asım Bey Armonizasyon: Callisto Guatelli Armonik Analiz: S. Uğraş Durmus
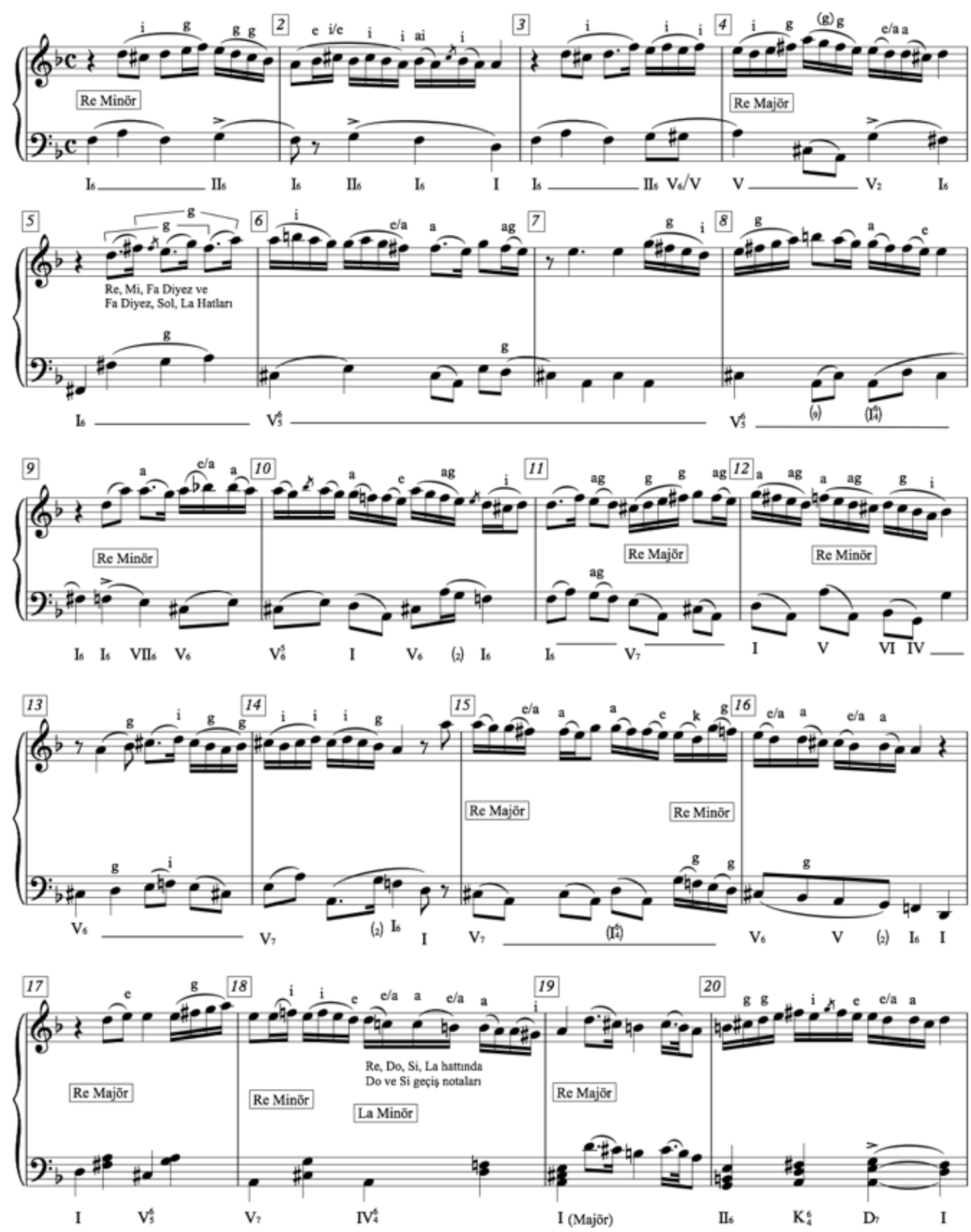

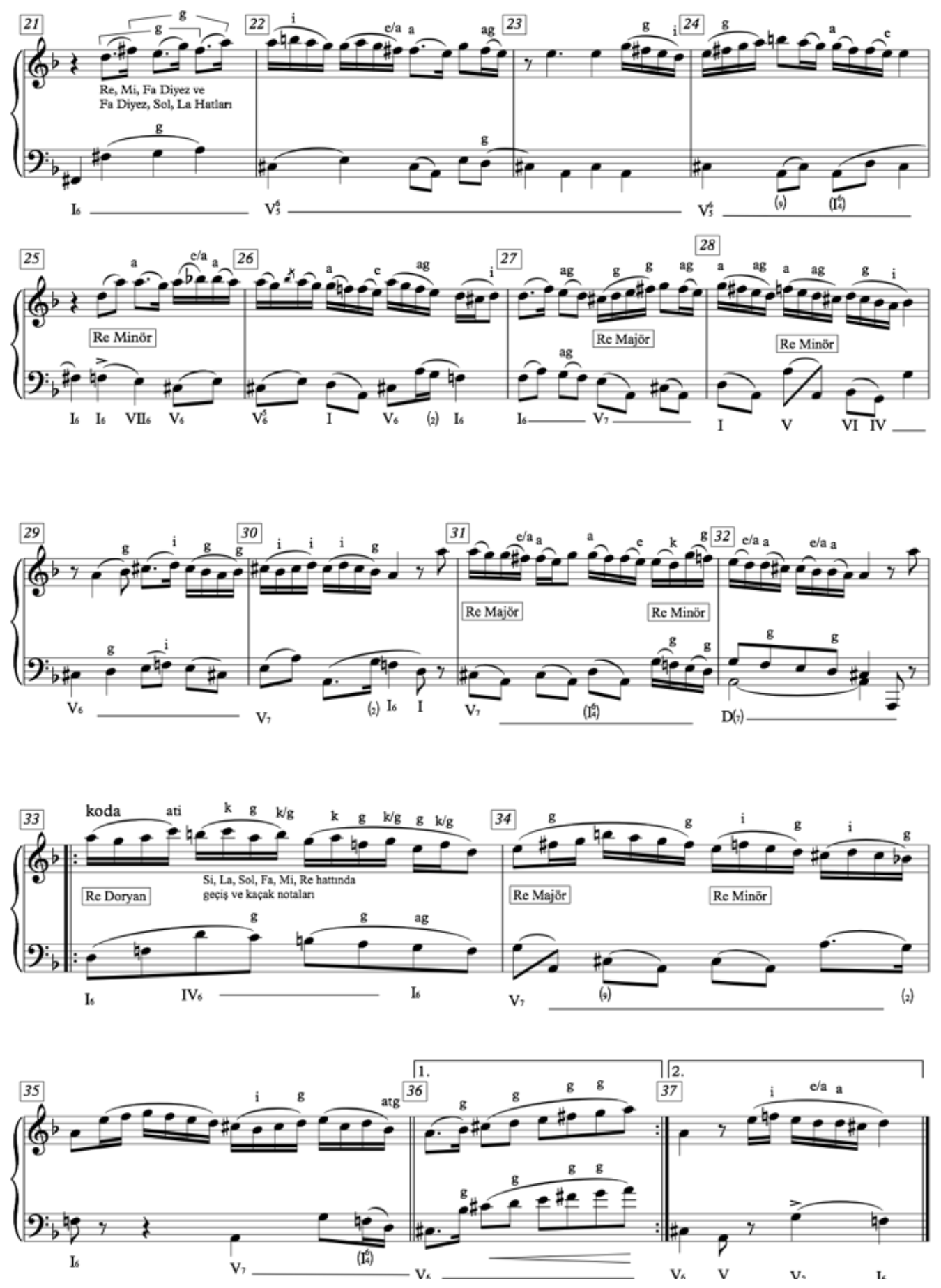


\section{UŞŞAK ŞARKI}

Orijinal Eser: Ethem Bey

Armonizasyon: Callisto Guatelli Armonik Analiz: S. Uğraş Durnuş
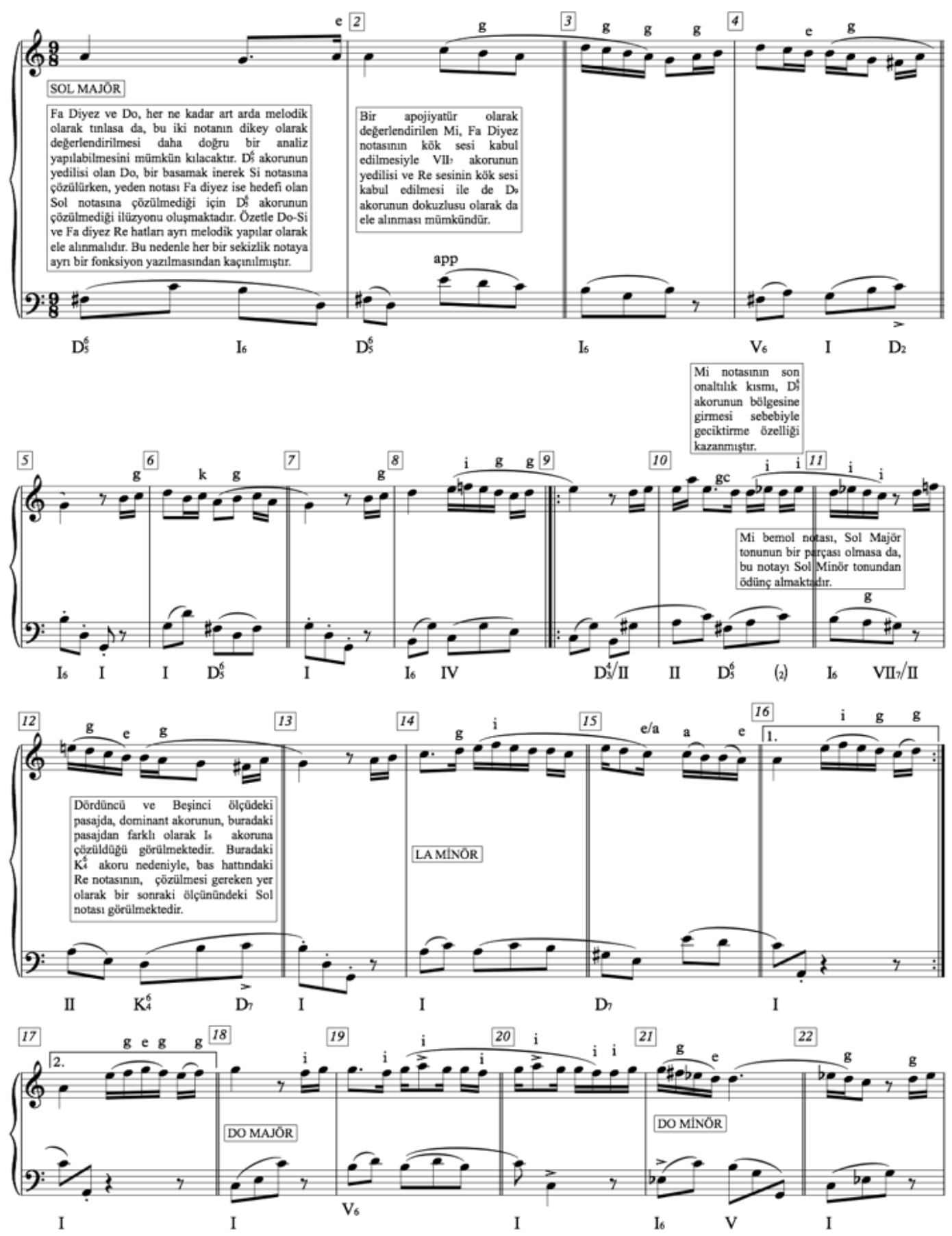

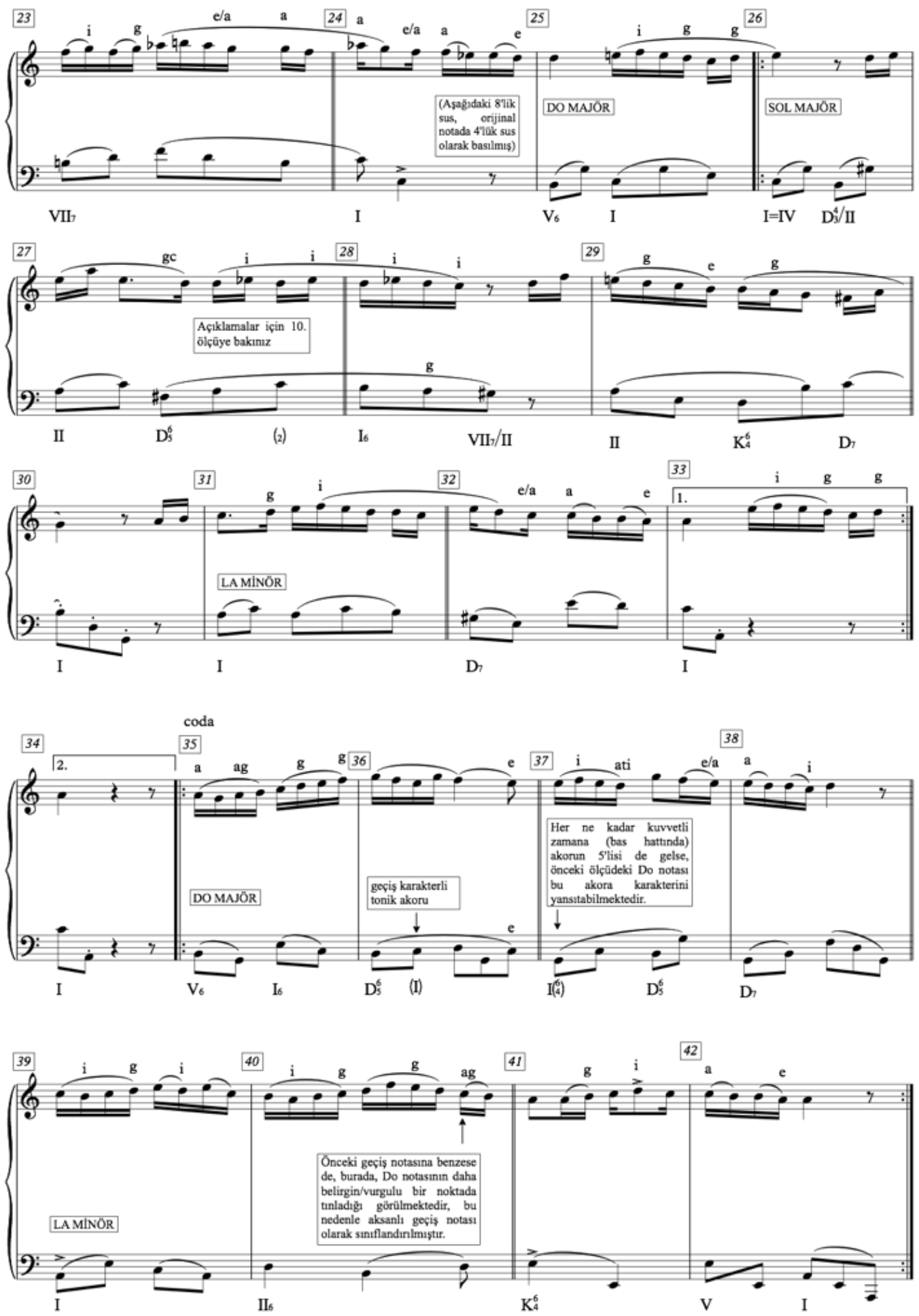


\section{Sonuç}

Guatelli'nin

yapmıș armonizasyonlardan seçilen iki örnek, sunulan bulgular ıșığında farklı perspektiflerden incelenerek, çağdașları ve daha önceki sanatsal üretimlerin referans alınmasının da yardımı ile tarihsel süreç ve estetik düzleminde konumlandırılmaya çalıșılmıș ve buna ek olarak yapılan armonik analizlerin sağladığı veriler ıșığında da yapısal iskeletin aydınlatılması hedeflenmiștir. Eserlerin müzik sanatı ile müzik tarihindekiyerinin veöneminin sağlıklı bir șekilde değerlendirilebilmesi için tercih edilen araștırma yöntemi kapsamında, sadece dikey eksende (armonik yapısı) yapılan bir çözümlemenin sunduğu veriler değil, aynı zamanda bu yapitların oluşturulması için motivasyon sağlamıș olduğu düșünülen nedenlere de değinilerek, dönemin kültürel dokusu ile olan uyumu da incelenmeye çalıșılmıștır. Yapıtların dokusu, dikey ve yatay eksendeki organizasyonu, makamların dönüşüumü/asimilasyonu ve bu bașkalașmış melodik hatların tonal çerçeve ile ilișkilendirilmesi, tarih ve müzik teorisi penceresinden incelenmiş ve bazı sonuçlara ulașılmıștır.

Musika-i Hümâyûn'un kurulması ile Osmanlı kültürünün her katmanında etkisini artıran ve kabul gören Batı müziği, aynı dönemde Türk müziği ile etkileșime girmiș ve bunun sonucunda her iki müziğin de etkilerini taşıyan melez yapıda eserler literatürde yer almaya bașlamıștı. Bu nedenle Guatelli'nin bu yöndeki çalıșmalarını, bestecinin bireysel çaba ve arayıșı olarak değil, dönemin kolektif eğiliminin bir yansıması olarak değerlendirmek daha doğru olacaktır. Türk müziği literatüründen seçilen eserlerin çokseslendirilme sürecinde 12 ses eșit tamperaman sistemine taşındığını ve bu nedenle makamların karakteristik tını paletini yitirdiğini görebilmekteyiz. Geleneksel lezzetlerinden uzaklașıp tonal çerçeveye bir adım daha yaklașan bu ses örgüsünü bu șekliyle armonize edilmiş olması besteci tarafından tercih edilmiș bir yol olabilir. Dönemin armoni anlayıșı göz önünde bulundurulduğunda, seçilen makamsal eserlerin tonal çerçeveye yerleștirilebilmesinin mümkün olabilmesi için bu tip bir asimilasyona ihtiyaç duyulduğunu söylememiz yanlış olmayacaktır. Ușşak veya Hicaz makamında yazılmıș bu eserlerin, geleneksel perdelerini koruyarak tonal müzik estetiğinde çokseslendirilebilmesi teorik olarak pek mümkün görünmemektedir.

Makamların "12 ses eșit tamperaman" sistemine tașınma sürecinde, söz gelimi Doryan, Frigyen gibi Ortaçağ modlarını andırabilecek noktalara doğru yelken açması sebebiyle, eserlerin besteci tarafından Rönesans polifonisi estetiği çerçevesinde çokseslendirilmesi beklenebilirdi. Rönesans Dönemi'nin en tanınmış bestecilerinden biri olan G. P. Da Palestrina gibi bir figür ile aynı topraklarda yetișmiș bir müzisyen olarak, Guatelli, modal polifoniyi makamsal eserlerin çokseslendirilmesinde kullanılabilecek bir araç olarak ele alabilirdi. Bu tür bir yaklașım makamların çokseslendirilmesinde tonal bir yaklașıma göre daha esnek bir çalıșma alanı sunabilir ve makamsal eserlerin eksenine sadık kalınması sağlanabilirdi. Tonal yapının ekseninin de, makamsal yapının ekseni gibi La notasına sabitlenip diğer dereceleri daha modal bir perspektifte ele alınabilmesi teknik olarak mümkünken, bestecinin, eseri tonal bir yapıya entegre etme arzusunun 
sonucu çok miktarda eksen değișikliğinin (modülasyon/geçki) armonizasyona yansıtılmıș olduğu görülebilmektedir

İncelenen eserlerin armonik dilinde bazı ilginç noktalar göze çarpsa da, daha geniş bir açıdan bakıldığında, makamsal müzikten alınan bu melodik yapıların armonize etmek için tercih edilen araçların kullanımında özgün bir yaklaşım sergilenmediği görülmektedir. Dönemin armonik diline yakın bir renk yelpazesi çerçevesinde armonizasyonunu yapan Guatelli'nin, çokseslendirdiği eserlerin özgün ses örgüsünü göz önünde bulundurmadığı sunulan bulgular ıșığında ulaşılan diğer bir sonuçtur. Öte yandan, 19. yüzyıl müziği estetiğinde modalite kavramının henüz 20. yüzyıldaki kullanımı ile karșılaștırılabilecek bir noktaya ulașmaması nedeniyle, İtalyan müzik insanının ortaya koyduğu müzik yapıtını tonal çerçeveye yerleștirme gayretini o devrin doğal bir besteci refleksi olarak görebiliriz. Romantik dönemin bizlere armağan ettiği eșsiz piyano literatürünün eserleri ile karșılaștırıldığında, doku bağlamında oldukça sade bir yapının tercih edildiği görülebilmektedir. Chopin, Liszt gibi dönemin öne çıkan besteci/virtüöz figürlerin eserleri ile karșılaștırıldığında, piyano yazı dilinin çağdaşları gibi üst düzey bir olgunluğa ulaștığını söylemek pek mümkün görünmemektedir. Bu dokunun tercih edilmesindeki ana belirleyici sebep, estetik kaygının dışında, parçaların müzisyenler tarafından kolaylıkla icra edilmesini sağlayarak yapitların daha geniș bir kitleye ulaștırma arzusu olabilir. Günümüz perspektifinden bakıldığında, bu konuda net bir şey söylemek oldukça güç olsa da, bestecinin böyle bir yöntemi tercih etmiș olma olasılığının da göz ardı edilmemesi gerekmektedir. Tarihsel süreçte, makam müziğinin çokseslendirilmesi için yapılan çalıșmaların bir parçası olarak görülmesi gereken bu armonizasyonlar, bu konuda gösterilebilecek en ideal örnekler olmasa da, bestecinin bilinçli ya da sezgisel olarak müziğe eklediği elementlerle kendinden sonra gelen bestecilere 1 şık tutmuş olması oldukça değerlidir.

\section{Kaynakça}

Alimdar, S. (2016), Osmanlı'da Batı Müziği, İstanbul: Türkiye İș Bankası Kültür Yayınları

Aracı, A. (2011), Kayıp Seslerin İzinde, İstanbul: Yapı Kredi Yayınları

Bakihanova, Z. (2003), Armoni, Ankara: Bilkent Üniversitesi

Baydar E. K. (2011), “19. Yüzyıl Padișahlarının Müzik Politikalarından Kesitler", YDÜ Sosyal Bilimler Dergisi, $4 / 1$, s. $92-111$

Cangal N. (2010), Armoni, Ankara: Arkadaș Yayınevi

Hanönü Y. (2014), “Callisto Guatelli’nin 19. Yüzyıl Klasik Türk Müziği Çokseslendirme Çalıșmalarındaki Yeri, Eserlerinin Transkripsiyon ve Analizi", Doktora Tezi, İnönü Üniversitesi

Gazimihal, M. R. (2019), Türk Askerî Muzikaları Tarihi, İstanbul: Doğu Kütüphanesi

Karul ilyas, Y. (2020), Piyanonun Osmanlı'daki Serüveni, Ankara: Nobel Yayın 
Kennan, K. W. (1972), Counterpoint, The Analysis of Callisto Guatelli's New Jersey: Prentice-Hall harmonizations of the makam pieces by Giriftzen Asım Bey and Ethem Bey;

Michels U. ve Vogel G. (2015), Müzik Atlası, İstanbul: Alfa Müzik importance and place in music history and music theory

Özkan, i. H. (2000), Türk Mûsıkîsi Nazariyatı ve Usulleri Kudüm Velveleleri, İstanbul: Ötüken Neșriyat Yayınevi

Piston, W. (1969), Harmony, Amerika Birleșik Devletleri: W. W. Norton\&Company

Roeder, M. T. (2003), The History Of Concerto, Portland: Amadeus Press

Schenker, H. (2001) Counterpoint, Michigan: Musicalia Press

Şenel, O. (2021), “MüzikteMükemmelliğin Göreceliği: Akort Sistemlerinin Evrimi ve Eșit Tampere

Sistemin Yükseliși”, Uluslararası Sosyal Araștırmalar Dergisi, 14/76, s. 352-269

Tanzimat'tan Cumhuriyet'e Türkiye Ansiklopedisi (1985), Bülent Aksoy 5. Cilt, İstanbul: İletişim Yayınları,

Toker, H. (2016), Elhan-1 Aziz Sultan Abdülaziz Döneminde Sarayda Mûsikî, Ankara: TBMM Milli Saraylar

The Bath Chronicle (1861), "Turkey”, 11 Temmuz 1861 Perșembe, s. 6

Youtube (2020), Early Music Sources, "Temperaments-What You Should Know", video, erișim 15

Nisan 2021, https://www.youtube.com/ watch?v=TgwaiEKnMTQ 


\section{The Analysis of Callisto Guatelli's harmonizations of the makam pieces by Giriftzen Asım Bey and Ethem Bey; importance and place in music history and music theory}

\section{Extented Abstract}

The westernization movement in Ottoman Empire had a profound impact on music culture in the nineteenth century. After the abolition of Mehterhane (Ottoman army band) in 1826, a Western type of military band was established by Sultan Mahmud II. The band was founded under the roof of the musical foundation called Musika-i Hümâyûn. Professional musicians who were trained in the Western music field, such as conductors, educators and performers were invited and employed in Musika-i Hümâyûn. Well-known Italian composer Gaetano Donizetti's (17971848) brother Giuseppe Donizetti (1788-1856) was one of the most influential figures among all of them. He contributed, the Western music culture to receive acceptance and to spread both at the government and society level. After death of Donizetti in 1856, a second Italian maestro continued his legacy. Callisto Guatelli (1818-1900) was the successor of Donizetti. Guatelli served to Ottoman music life in various roles as conductor, composer, performer and educator. His compositional output mainly consist of marches and other military music influenced forms. Besides Western style of compositions, he also focused on traditional makam music. He composed some piano pieces consisting of inspirations from Turkish makam music and also harmonized various pieces from the makam music repertoire.

In this study two chosen harmonizations of Guatelli were analyzed. With the data derived from harmonic analysis, the path that Guatelli might have followed, was tried to be revealed. Hybrid structure of the pieces were analyzed both from makam and tonal music perspectives. Due to different pitch organizations of Ottoman-Turkish and Western music, harmonized songs' sonic palette altered significantly. The possible reasons of this transformation was tried to be explained. Additionally, this study focused on shifting sonic palettes of makam structures during the harmonizing process. By comparing the texture of the pieces with his European contemporaries, the harmonizations were tried to be positioned in the Romantic era.

Harmonizing a piece which was composed in makam aesthetic, brings a couple of major difficulties. Perhaps the most important challenge to overcome is that harmonized songs or pieces consist of notes that can not be performed on a piano which is tuned in 12 tone equal temperament system. Both in Turkish makam theory and practice, intervals which are smaller than a semitone are essential. While in makam music theory they are called koma, from Western music theory point of view, the tones which do not fit into 12 tone temperament system are called microtones. As komas are the building blocks of makam structure, adapting such "microtonal" music to equal temperament system will cause to lose authenticity and taste of the original piece. At this stage of harmonizing, composers' attitudes play a critical role in harmonizing a piece taken from makam music literature. Guatelli, as a Romantic era composer, embraced a tonal approach (rather than a modal approach) for these harmonizations. The original songs were transferred from microtonal sonic tone palette to the equal temperament, thus, tonal harmony became an applicable tool. Guatelli adapted the transformed melodic structures into a tonal framework. The harmonic analysis of these pieces provides the data that, tonal centre of the harmonizations and the original pieces are not consistent. The reason behind this inconsistency is, with the help of the tonicization of the certain notes/degrees of the makam scales, Guatelli could make it possible to adapt the melodies into tonal system. On the one hand, this approach made it possible to harmonize the non-tonal melodies, but on the other hand, the notes, which do not have a tonic character in the makam theory, had new roles and functions. 
In the Romantic era, virtuosity has had great importance. Composers like N. Paganini (1782-1840), F. Liszt (1811-1886), F. Chopin (1810-1849) were among the most influential figures of the period. Romantic piano literature is mostly decorated with complicated and dense texture, whereas Guatelli's analyzed harmonizations do not bare such characteristic structure.

On the one hand, the hybrid structure of the harmonizations made it possible to create a unique musical language, but on the other hand, because of the pitch organization of the makam structures, in the frame of equal temperament, original songs lost their identities and taste at a significant level. The path that Guatelli followed to achieve to harmonize pieces taken form makam music literature has great importance as they were one of the first examples of this compositional approach.

\section{Keywords}

harmonization, Turkish music, makam, Ottoman Empire, polyphony 
